\title{
Oligotrophic patterns in southern Chilean lakes: the relevance of nutrients and mixing depth
}

\author{
Patrones oligotróficos en lagos del sur de Chile: relevancia de los nutrientes y de la \\ profundidad de mezcla
}

\begin{abstract}
DORIS SOTO
Facultad de Pesquerías y Oceanografía, Instituto de Acuicultura, Universidad Austral de Chile, Casilla 1327 Puerto Montt, Chile; e-mail: dsoto@uach.cl
\end{abstract}

\begin{abstract}
Southern Chilean monomictic, temperate lakes are generally oligotrophic with high water transparency, low productivity and some apparent resistance to disturbances such as phosphorus additions. This paper attempts to explain low chlorophyll-a values using descriptive and experimental approaches. Three different scales are used, (a) a micro scale both in space and time, with experimental manipulations of N, P and total light in 24 enclosures in lake Llanquihue, (b) a longer time scale analysing 18 months of data in several sites within lake Llanquihue grouped as salmon farming sites, town bays and control sites, and (c) a broader time scale ( 9 years) by monitoring lakes Puyehue, Rupanco and Llanquihue, all in the Araucanian lake region and Yelcho lake in the north Patagonian region. In the Llanquihue in-lake sampling, total phosphorus values varied between 1 and $12 \mu \mathrm{g} \mathrm{L}^{-1}$ between sites, showing marginal site effects, $\mathrm{P}=0.09$ (salmon sites had greater values), however, chlorophyll a (Chl-a) concentrations were generally low $\left(<2 \mu \mathrm{g} \mathrm{L}{ }^{-1}\right)$ and did not show site effects. Dissolved inorganic nitrogen (DIN) concentrations were lower than $30 \mu \mathrm{g} \mathrm{L}^{-1}$ and showed a better predictive power than Chl-a. The analysis between lakes showed the lowest mean Chl-a values in Lake Yelcho $\left(0.7 \mu \mathrm{g} \mathrm{L}^{-1}\right)$ and the highest in lake Puyehue $\left(2.1 \mu \mathrm{g} \mathrm{L}^{-1}\right)$. Similar patterns were found for mean total $\mathrm{P}$ values, however there were no clear temporal trends through the 9 year sampling. The N/P molar ratio for the dissolved forms was generally below 20 . In the enclosure experiment $\mathrm{N}$ had a positive significant effect on Chl-a concentration but neither P nor light had significant effects. Another outstanding result was that Chl-a values in the control bags were significantly higher than values in the lake. In all the lakes TN values did not exceed $20 \mu \mathrm{mol} \mathrm{L}^{-1}$ and TP did not exceed $0.8 \mu \mathrm{mol}$ $\mathrm{L}^{-1}$ and thus $\mathrm{N}$ limitation could be proposed as playing an important role in regulation Chl-a and productivity. Another key-regulating factor of productivity and biomass could relate to the deep mixing which is a particular characteristic of Southern Hemisphere lakes, indeed, mixing depth has a negative effect and yields the best predictive power on Chla. This effect could also explain Chl-a increase in control bags with respect to lake since the epilimnion is artificially reduced in the former. If mixing depth influences productivity, then lake food webs should be linked to the benthos rather than to the pelagic zone particularly in the deepest mixing lakes.
\end{abstract}

Key words: oligotrophy, mixing depth, nitrogen, temperate lakes.

\section{RESUMEN}

Los lagos monomicticos templados del sur de Chile son generalmente oligotróficos de gran transparencia, baja productividad y aparente resistencia a perturbaciones tales como adiciones de fósforo. Este trabajo intenta explicar los bajos valores de clorofila de acuerdo a aproximaciones descriptivas y experimentales. Se utilizan aquí tres escalas de aproximación; (a) una microescala en espacio y tiempo con manipulaciones experimentales de nitrógeno $(\mathrm{N})$, fósforo (P) y luz en 24 limnocorrales ubicados en una bahía del lago Llanquihue, (b) una escala mayor analizando 18 meses de muestreo en 10 sitios del lago Llanquihue agrupados como sitios de cultivo de salmones, bahías de ciudades y sitios de control, (c) una escala aún mayor en tiempo y espacio monitoreando semestralmente por 9 años los lagos Puyehue, Rupanco, Llanquihue en la región de los Lagos Araucanos y el lago Yelcho en la región nor- patagónica. En el muestreo intra lago en el Llanquihue, los valores de fósforo total variaron entre 1 y $12 \mu \mathrm{g} \mathrm{L}^{-1}$ en los distintos sitios, mostrando efecto de sitio marginales, $\mathrm{P}=0,09$ (sitios de cultivo de salmones tuvieron los valores mayores). Sin embargo las concentraciones de clorofila a (Chl-a) fueron generalmente bajas $\left(<2 \mu \mathrm{g} \mathrm{L}^{-1}\right)$ y no indicaron efectos de sitio. Las concentraciones de nitrógeno orgánico disuelto (DIN) fueron menores que $30 \mu \mathrm{g} \mathrm{L}^{-1}$ y mostraron mejor poder predictivo sobre las variaciones de Chl-a. El análisis entre lagos mostró los valores mas bajos de Chl-a en el lago Yelcho $(0,7 \mu \mathrm{g}$ $\left.\mathrm{L}^{-1}\right)$ y los mayores en el lago Puyehue $\left(2,1 \mu \mathrm{g} \mathrm{L}^{-1}\right)$. Los valores de $\mathrm{P}$ total mostraron un patrón similar sin embargo no hubo tendencias temporales claras en los 9 años de muestreo. La razón molar N/P para las formas disueltas fue generalmente menor que 20. En el experimento en limnocorrales el $\mathrm{N}$ tuvo un efecto significativo positivo $(\mathrm{P}<0,001)$ sobre la concentración de Chl-a en cambio ni el P ni la disponibilidad de luz mostraron efectos significativos. Otro resultado notable fue que la concentración de Chl-a fue superior en los limnocorrales control que en el lago. En todos los lagos estudiados los valores de $\mathrm{N}$ total no excedieron $20 \mu \mathrm{mol} \mathrm{L}^{-1}$ y las concentraciones de $\mathrm{P}$ total no superaron los 
$0,8 \mu \mathrm{mol} \mathrm{L} \mathrm{L}^{-1}$ lo que sugeriría particularmente una limitación por $\mathrm{N}$ como un elemento clave en la regulación de la Chla y productividad. Un factor adicional regulador de la productividad y biomasa, y que solo se evalúa indirectamente aquí, sería la gran profundidad de mezcla, característica peculiar de los lagos templados del hemisferio sur y que tiene un mejor poder explicativo, afectando negativamente la concentración de Chl-a de los lagos. Su efecto también puede explicar el aumento de la Chl-a en los limnocorrales con un epilimnion forzadamente muy reducido. Si la gran profundidad de mezcla condiciona la productividad, entonces las tramas tróficas de los lagos de profundo epilimnion debieran estar mas ligadas al bentos y zonas costeras.

Palabras clave: oligotrofía, profundidad de mezcla, nitrógeno, lagos templados.

\section{INTRODUCTION}

Published information on the "Araucanian lakes" (Campos 1984) and southern Chilean lakes in general, including Patagonian lakes ( 39 to $52^{\circ} \mathrm{S}$ ), allows us to recognize aquatic environments that differ from the typical temperate lakes described in the literature. Some characteristics of these, monomictic, temperate lakes are; very low chlorophyll-a concentrations, high water transparency, low productivity and some apparent resistance to disturbances such as phosphorus additions (Soto et al. 1994, Soto \& Campos 1995). Comparisons between these lakes with other, similar lakes, of similar lake regions of the Northern Hemisphere, have shown that these Chilean lakes have chlorophyll a concentrations smaller than expected, according to the present phosphorus concentrations (Soto \& Stockner 1996). Similar conclusions were reached by Baigun \& Marinone (1995). Thus, a key question arising from these comparisons, relates to the mechanisms or processes maintaining oligotrophy in these Chilean lakes. Earlier studies suggested that $\mathrm{P}$ was a strong limiting factor (Campos 1984), however, frequently in these same water bodies the observed nitrogen: phosphorus ratio $(\mathrm{N}: \mathrm{P})$ for dissolved inorganic forms has been less than 10 (Soto et al. 1994). This suggests a potential $\mathrm{N}$ limitation, which could be an explanation for the low responses to increased loading of P (Soto \& Campos 1995). These lakes receive very little inorganic nitrogen from precipitation, as atmospheric deposition of $\mathrm{N}$ is very low, in some areas of the region where it has been considered one of the lowest in the world (Hedin et al. 1995, Galloway et al. 1996). Such a pattern could be attributed at least partly to the minimal industrial development in the southernmost part of South America as compared to almost anywhere in the Northern Hemisphere.

Due to great water transparency, exposure to total radiation and, additionally, a high exposure to UV radiation can be argued as another possible mechanism regulating lake responses to the addition of nutrients. The occurrence of photosynthesis inhibition or photoprotection in the first meters in depth of a water body due to excess radiation is well known (Neale 1987, Neale et al. 1991,
Vincent et al. 1994). Negative effects on photosynthesis due to UVA or UVB exposure have also been suggested (Villafañe et al. 1999). Such effects could be particularly relevant in lakes with very transparent waters containing very low dissolved organic carbon and suspended solids concentrations (Schindler 1997). Such is the case in lake Llanquihue, the largest and one of the deepest of southern Chile $\left(870 \mathrm{~km}^{2}\right.$ and $340 \mathrm{~m}$ depth). Until 1992 this lake showed and average Secchi disc of $19 \mathrm{~m}$ in the lake's center and average Secchi disc readings between 14 and $16 \mathrm{~m}$ within bays with high human disturbance (Soto \& Mena 1999). Lake Ranco, another large lake in the region, has shown an average secchi disc of $14 \mathrm{~m}$ despite increasing P inputs (Soto \& Campos 1995). On the other hand, dissolved organic carbon (DOC) content of most of these lakes is lower than $1 \mathrm{mg} \mathrm{L}^{-1}$ (Steinhart 1996).

In general, in high transparency lakes, greater photoinhibition is expected than in less transparent lakes since in the latter, suspended particles could interfere with light transmission. At the same time, in high transparency lakes deep chlorophyll maxima are expected (Vincent et al. 1984) which could be due to PAR and/or to UVR. Greater UVR penetration due to low DOC concentration (Morris et al. 1995, Schindler 1997) could promote a sort of resilience to nutrient inputs, by buffering phytoplankton and productivity responses.

On the other hand, Chilean oligotrophic lakes located between 39 and $44^{\circ} \mathrm{S}$ have comparatively small watershed basins for their sizes and depth (compared to literature data) and receive large proportion of water from direct precipitation, which is usually very clean particularly regarding nitrogen as mentioned before, such is the case of lake Llanquihue (Fig. 1). However, human activities around and within the lakes are increasing rapidly, namely agriculture, urban development and also salmon farming. At present, about $50 \%$ of the salmon smolt production is achieved in these lakes, which represent a potentially large nutrient input to them.

This paper shows data series from four lakes, which have variable N/P ratios and attempts to explain low chlorophyll values according to these 
data and by experimental manipulation of $\mathrm{N}$ and $\mathrm{P}$ concentration and light exposure. Three different scales are used; (a) a micro scale both in space and time, with experimental manipulations in one bay in Lake Llanquihue, (b) a larger time scale analyzing 18 months data in several sites within Lake Llanquihue, and (c) a broader time scale (9 years) of monitoring four lakes in the Araucanian lake region including lake Llanquihue. Data of other known lakes of the same region are used as well for comparison. Also by comparing with

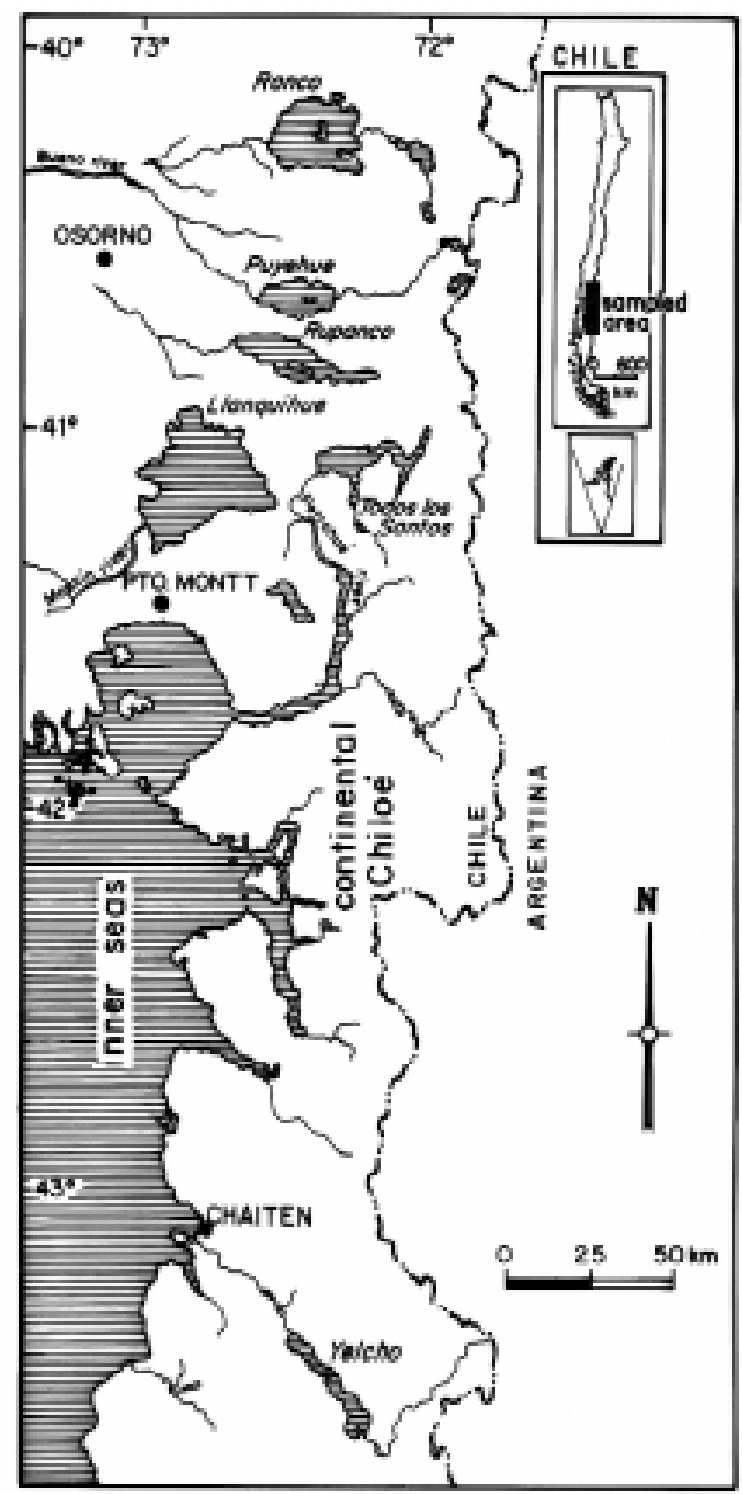

Fig. 1: Sampled lakes Puyehue, Rupanco and Llanquihue in the Araucanian lake region and lake Yelcho, further south in the north Patagonian region.

Lagos muestreados, Puyehue, Rupanco y Llanquihue en la región de los lagos Araucanos y el lago Yelcho mas al sur en la región Patagónica nortina.
Southern Hemisphere and Northern Hemisphere lakes I attempt to contrast and propose new mechanisms to explain oligotrophy in these Chilean lakes, and in Southern Hemisphere lakes in general.

The mixing of different spatial and temporal scales plus the experimental manipulation of variables it is an "a posteriori" approach attempting to emphasize patterns and processes, which override such scales and thus could help to build a stronger argument. The use of salmon farming sites also helps to test local effects of additional nutrient pulses, as a way of mensurative experiment.

\section{MATERIAL AND METHODS}

Limnological evaluations to lakes: seasonal sampling and in-lake comparison

Between August 1990 and August 199210 sites were sampled within lake Llanquihue $\left(41^{\circ} 08^{\prime} \mathrm{S}\right)$. Sites included five bays that had salmon farming in floating pens, three town bays, and two control sites, one of them in the central and deepest part of the lake. Control sites represent more than 80 $\%$ of lake surface while included bays represent well the present uses and conditions of coastal zone of the lake where eutrophication symptoms could develop early on.

Sampling of limnological variables was done every two months in some sites and others, were simultaneously sampled every month. To collect samples for water chemistry, three samples were taken with a Van-Dorn bottle at 0,10 and a near bottom (15 to $40 \mathrm{~m}$ ) and mixed in a plastic bottle previously acid washed, thus producing one integrated sample for the epilimnion. In all the sites, except the central - control or reference site, this water column ( 15 to $40 \mathrm{~m}$ ) represents mostly the epilimnion during summer. This epilimnion may be as deep as $50 \mathrm{~m}$ in this lake at the end of the summer, thus all the coastal salmon farming and town bays usually do not stratify during summer.

On each date and site, samples for chlorophyll and phytoplankton were integrated from a 1-m, 8$\mathrm{m}$ and $15-\mathrm{m}$ sample. Samples for chlorophyll a (Chl-a thereafter) were obtained after filtering 3 liters of water through $\mathrm{GF} / \mathrm{F}$ filters $(0.45 \mu \mathrm{m})$. The filters were dried and kept cold in aluminum foil envelopes. These samples were analyzed in the laboratory within 8 to $12 \mathrm{~h}$ of collection in a spectrophotometer, after acetone extraction.

Samples for water chemistry were brought in ice to the laboratory where they were kept frozen $\left(-20^{\circ} \mathrm{C}\right)$ until analyzed, usually within one to 
three days of being collected. All analyses have been done following methods described by Wetzel \& Likens (2000) except for $\mathrm{NO}_{3}-\mathrm{N}$ which was analyzed spectrophotometrically after sodium salicilate treatment (Campos et al. 1992). The sum of the nitrogen content of the three dissolved inorganic forms $\left(\mathrm{NO}_{2}, \mathrm{NO}_{3}\right.$ and $\left.\mathrm{NH}_{4}\right)$ is presented as dissolved inorganic nitrogen (DIN). Although total nitrogen (TN) was also measured and organic nitrogen was calculatewd, DIN values were mostly used for general comparisons since these are considered more reliable measurements at the present laboratory conditions used. Total phosphorus and $\mathrm{PO}_{4}$ were also analyzed as described by Wetzel \& Likens (2000) and the ratio between DIN and $\mathrm{PO}_{4}$ (DIN/DIP) was calculated. Total nitrogen (TN) was analyzed after Kjeldahl method (Campos et al. 1992). Integrated water samples were taken for zooplankton and phytoplankton between 0 - and 20-m depth, although only phytoplankton samples will be referred to in this paper. Phytoplankton was collected directly from Van-Dorn bottle samples from five depths in the water column and the full sample was preserved with iodine solution. Identification and counts were performed with the Utermöhl method in 10$\mathrm{ml}$ chambers with an inverted microscope.

\section{Long term follow up: "between-lake" compari- son}

Starting in 1992 limnological evaluations have been made twice a year in two sites located near salmon farming areas in three lakes, Llanquihue, Rupanco (40 $50^{\prime} \mathrm{S}, 72^{\circ} 26^{\prime} \mathrm{W}$ ), and Puyehue $\left(40^{\circ} 10^{\prime} \mathrm{S}, 72^{\circ} 28^{\prime} \mathrm{W}\right)$ in the Araucanian Lakes Region, southern Chile (Fig. 1). This Lake District includes about 20 large temperate, monomictic, deep, glacial lakes located within the temperate rain forest region in southern Chile. These lakes have been described previously (Campos 1994, Soto \& Campos 1995). A fourth lake of similar characteristics, Yelcho, located in the north Patagonian region $\left(43^{\circ} 18^{\prime} \mathrm{S}, 72^{\circ} 19^{\prime} \mathrm{W}\right)$, has been sampled with similar periodicity.

Sampling was performed usually by the end of March, the last portion of the austral summer when lakes are still stratified and often reach maximum heat intake, and at the end of August or early September, at the end of the winter circulation when usually the first peak of algae and Chla take place. The two sampling sites were located approximately $3,000 \mathrm{~m}$ apart from each other and considered a water column of 35 to $75 \mathrm{~m}$ from the bottom up, one was closest to the salmon farm and the other performed as a control. One of the sampling objectives was to evaluate the environmental conditions for salmon farming, however this is not being discussed here. However it should be clarified that water chemistry did not differ among salmon farming sites and control sites.

On each late summer sampling date, two integrated samples were taken as described above: one from the epilimnion and another from the hypolimnion. However, because the epilimnion was very deep, and oxygen was well distributed through the bottom, only the latter data was used for the purpose of the comparison. In the spring, on each site, one sample was collected from the whole water column, integrating individual samples from 0- $\mathrm{m}, 15-\mathrm{m}$ and a near bottom sample.

Water chemistry, chlorophyll and phytoplankton analyses have been performed as described for the "in-lake" study (see above). For the "between-lake" comparison, the same sampling and analysis methodology was kept without major variations through the 9 years of sampling.

To reach a broader perspective, published data on other lakes of the region were used. These included the review by Soto \& Campos (1995) on the Araucanian lakes and data from other particular studies such as Patagonian lakes Toro and Sarmiento (Soto et al. 1994), lakes Villarrica and Riñihue (Campos et al. 1983, 1987), lakes Riesco and Elizalde (Campos et al. 1996). In most cases water chemistry and Chl-a analysis followed the same methodology described here. In all these cases data represent one to two years of study with monthly measures.

\section{Short term experiment: limnocorral manipula- tion}

During the summer of 1995 a limnocorral experiment was performed to evaluate $\mathrm{N}$ and $\mathrm{P}$ effects on phytoplankton biomass in Totoral bay, lake Llanquihue ( $\left.41^{\circ} 08^{\prime} \mathrm{S}, 72^{\circ} 47^{\prime} \mathrm{W}\right)$. The limnocorrals were bags made of sturdy transparent plastic, 80 $\mathrm{cm}$ in diameter and $2 \mathrm{~m}$ in depth. Each bag was attached to a wooden frame built on a double floating platform. Each section of the platform contained 12 units (bags), each one of them remained in vertical position once filled with lake water. Each bag was filled with an electric pump whose hose had a $200-\mu \mathrm{m}$ pore screen to exclude large zooplankton and other particles.

On January 151995 the experiment started by assigning one of four treatments to each bag in a factorial design where $\mathrm{N}$ and $\mathrm{P}$ concentration were manipulated in each bag. Thus, there was a control treatment (no nutrients added), $\mathrm{N}$ addition, $\mathrm{P}$ addition and both $\mathrm{N}$ and $\mathrm{P}$ addition. Each 
treatment had three replicates. At the same time, in another adjacent raft, the same treatments were assigned to the other 12 bags, which were covered by a plastic fiber netting which reduced total radiation by about $49 \%$, producing a block design such that 12 bags received full light and 12 received half-light. In each block, treatments were assigned in a systematic way assuring interspersion.

Each $\mathrm{N}$ treatment bag received a pulse of $\mathrm{N}$ as ammonium chloride to reach a final concentration of $15 \mu$ moles $\mathrm{L}^{-1}\left(210 \mu \mathrm{g} \mathrm{L}^{-1}\right)$. Conversely, $\mathrm{P}$ bags received $\mathrm{P}$ as $\mathrm{NaH}_{2} \mathrm{PO}_{4} 2 \mathrm{H}_{2} \mathrm{O}$, to reach final concentration of $1 \mu \mathrm{mol} \mathrm{L}^{-1}\left(31 \mu \mathrm{g} \mathrm{L}^{-1}\right)$, and bags which were assigned $\mathrm{N}$ and $\mathrm{P}$ treatments, received both nutrients to reach final concentrations as already described. Nutrient concentration achieved in each addition treatment was approximately one order of magnitude higher than in the lake and in the control bags for dissolved inorganic forms. Considering that nutrients are very quickly utilized and may be slowly recycled, the same amount of each nutrient was added every four days to each bag except the control.

Experiments were sampled on January 22, 26 and 30. On each occasion, water samples were taken with a peristaltic pump with a hose, which was immersed $60 \mathrm{~cm}$ below the surface inside each bag. From each bag, $100 \mathrm{ml}$ were filtered through Whatman GF/F filters, and pigments were extracted with $90 \%$ ethanol after acidification with $\mathrm{HCl} 0.1 \mathrm{~N}$ to extract phaeopigments. Chloro- phyll readings were done in a Turner 5000 fluorometer as described by Steinhart et al. (1999).

At each sampling, phytoplankton and nutrient water samples were collected for further analysis.

\section{RESULTS}

Seasonal and spatial variability in lake Llanquihue during the $1990-1992$ period

Total P values (TP) varied between 1 and $12 \mu \mathrm{g} \mathrm{L}$ ${ }^{1}$ among sites and lowest values were measured in the control sites while highest values were observed at the salmon bays (Table 1). An analysis of variance on yearly mean values showed marginal site effects on TP concentrations $(P=0.09)$. These were mostly due to higher values of TP on salmon farm sites than in control sites (paired Student ttest, $\mathrm{P}=0.048$, Table 1). Similar trends were observed for $\mathrm{PO}_{4}$, where concentrations often were below detection particularly in the control sites, although there were no significant statistical effects of sites with respect to $\mathrm{PO}_{4}$. Dissolved inorganic nitrogen (DIN thereafter), which represents $\mathrm{NH}_{4}+\mathrm{NO}_{2}+\mathrm{NO}_{3}$, varied between 3 and $50 \mu \mathrm{g} \mathrm{L}^{-1}$ although in most cases concentrations fluctuated around $20 \mu \mathrm{g} \mathrm{L}^{-1}$. Lowest values were usually observed during the 1991 summer, the later was true for both $\mathrm{P}$ and $\mathrm{N}$ (Fig. 2). Nitrate was the main component of DIN while $\mathrm{NH}_{4}$ was usually low and

\section{TABLE 1}

Limnological variables as measured in 10 sites along a year in lake Llanquihue. Mean values shown are obtained after averaging yearly site means. Standard error (SE) are indicated. Analysis of variance for site effect is shown as well as paired Student t-tests among group sites

Algunas variables limnológicas medidas a lo largo de un año en 10 sitios del lago Llanquihue. Los promedios aquí reportados se han obtenido promediando los valores medidos durante el año en cada sitio. Se indican los errores estándar (SE). Se muestra además los resultados del análisis de varianza para indicar efecto de sitio y las pruebas t de Student entre pares de grupos

\begin{tabular}{|c|c|c|c|c|c|c|}
\hline & & $\begin{array}{c}\mathrm{TP} \\
\left(\mu \mathrm{g} \mathrm{L}^{-1}\right)\end{array}$ & $\underset{\left(\mu \mathrm{g} \mathrm{L}^{-1}\right)}{\mathrm{PO}_{4}}$ & $\begin{array}{c}\text { DIN } \\
\left(\mu \mathrm{g} \mathrm{L}^{-1}\right)\end{array}$ & $\begin{array}{c}\text { Chl-a } \\
\left(\mu \mathrm{g} \mathrm{L}^{-1}\right)\end{array}$ & $\begin{array}{l}\text { Secchi } \\
\text { (m) }\end{array}$ \\
\hline $\begin{array}{l}\text { Control sites }(\mathrm{C}) \\
\mathrm{n}=2\end{array}$ & $\begin{array}{c}\text { Group mean } \\
\text { SE }\end{array}$ & $\begin{array}{c}3.5 \\
(0.3)\end{array}$ & $\begin{array}{c}1.5 \\
(0.1)\end{array}$ & $\begin{array}{l}17.4 \\
(2.5)\end{array}$ & $\begin{array}{c}1.3 \\
(0.3)\end{array}$ & $\begin{array}{l}17.3 \\
(1.2)\end{array}$ \\
\hline $\begin{array}{l}\text { Town bays (TB) } \\
\mathrm{n}=3\end{array}$ & $\begin{array}{l}\text { Group mean } \\
\text { SE }\end{array}$ & $\begin{array}{c}6.4 \\
(0.8)\end{array}$ & $\begin{array}{c}2.1 \\
(0.8)\end{array}$ & $\begin{array}{l}20.5 \\
(1.9)\end{array}$ & $\begin{array}{c}1.2 \\
(0.1)\end{array}$ & $\begin{array}{l}15.7 \\
(0.3)\end{array}$ \\
\hline $\begin{array}{l}\text { Salmon bays (SB) } \\
\mathrm{n}=5\end{array}$ & $\begin{array}{c}\text { Group mean } \\
\text { SE }\end{array}$ & $\begin{array}{c}6.9 \\
(0.8)\end{array}$ & $\begin{array}{l}2.26 \\
(0.28)\end{array}$ & $\begin{array}{l}23.57 \\
(2.21)\end{array}$ & $\begin{array}{l}1.56 \\
(0.13)\end{array}$ & $\begin{array}{l}13.53 \\
(0.95)\end{array}$ \\
\hline $\begin{array}{l}\text { ANOVA } \\
\text { Site effect } \\
\text { Paired t-tests }\end{array}$ & $\begin{array}{c}\text { P-value } \\
\text { C-SB } \\
\text { C-TB }\end{array}$ & $\begin{array}{c}0.09 \\
0.048 \\
0.08\end{array}$ & $\mathrm{~ns}$ & $\mathrm{~ns}$ & $\mathrm{~ns}$ & $\begin{array}{c}0.09 \\
0.08 \\
\mathrm{~ns}\end{array}$ \\
\hline
\end{tabular}




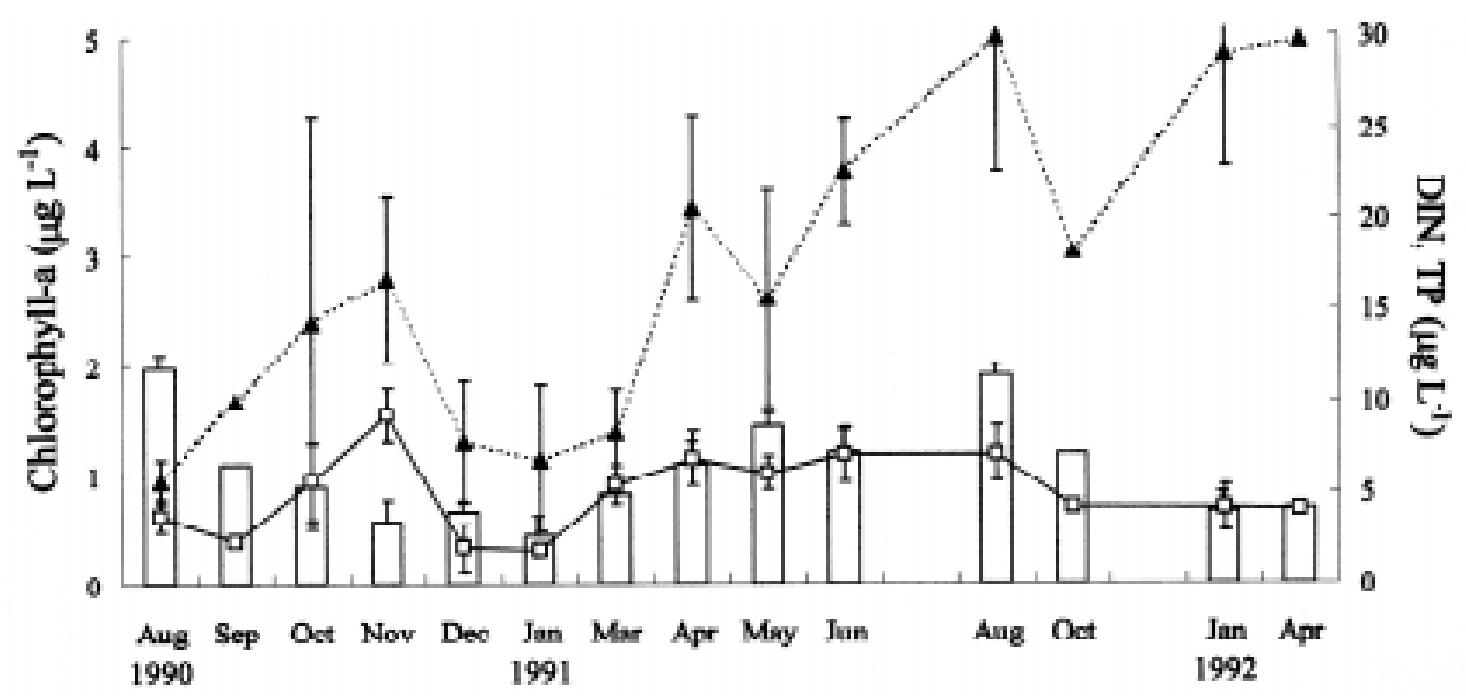

Fig. 2: Mean values of chlorophyll a (Chl-a) represented by bars, dissolved inorganic nitrogen forms (DIN), dashed line with triangles, and total phosphorus (TP) line with squares, of ten sampling stations in lake Llanquihue. Error bars are standard error.

Valores promedio para 10 estaciones de muestreo en el lago Llanquihue de clorofila a (Chl-a), representada por las barras, nitrógeno inorgánico disuelto (DIN) representado por línea discontinua con triángulos y fósforo total (TP) representado por líneas con cuadrados. Barras de error corresponden a error estándar.

often below detection. Site effects on DIN were not significant. Concentrations of Chl-a varied between less than $0.5 \mu \mathrm{g} \mathrm{L}^{-1}$ and $2.9 \mu \mathrm{g} \mathrm{L}^{-1}$ although values were more often closer to 1 . The highest Chl-a values were observed mostly in early spring (August-September) at all sites (Fig. 2) and there was no significant site effect as shown by the ANOVA analysis $(P=0.29)$. Secchi values showed little temporal variability and there was a marginal site effect on it, with the greatest Secchi depths in the control sites (Table 1), although this result can be misleading because often in salmon farm sites the Secchi disk can be seen on the lake bottom so the values can be underestimated.

Temporal and spatial variability was much greater for DIN than for TP (and $\mathrm{PO}_{4}$ ) and Chl-a showed the smallest variability among sites on each date (Fig. 2 and 3). There was no correlation between mean TP and Chl-a values and the regression slope was not significantly different from zero (Fig. 3A). This was also true when regressions were performed on individual data or on averages except for mean DIN values which had better predictive power on Chl-a (Fig. 3B).

Algal cell counts were generally low and varied in the range of 100 to 800 cells $\mathrm{mL}^{-1}$ while there were no significant differences among sites regarding the dominant group. The largest cell numbers and biomass which coincided with the highest Chl-a value took place in late August of 1990, the main phytoplankton component at that time was green algae and diatoms while a second algal
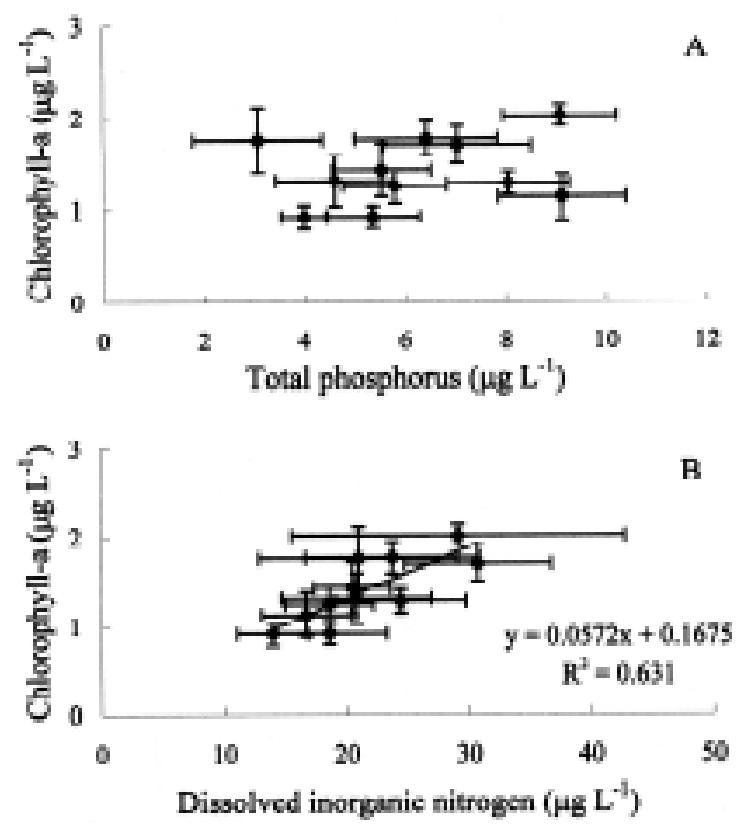

Fig. 3: Lake Llanquihue mean $(\mathrm{n}=10) \mathrm{Chl}-\mathrm{a}$ values and standard errors, plotted against mean values for total phosphorous (TP), above, and dissolved inorganic nitrogen forms (DIN), below. Regression line terms and $\mathrm{R}^{2}$ for the means is also indicated in the Fig. below.

Valores promedio de Chl-a y sus errores estándar versus valores promedio de fósforo total (TP), arriba, y versus valores promedio de nitrógeno inorgánico disuelto (DIN), abajo. Se muestra además la ecuación de regresión y valor de $\mathrm{R}^{2}$ para los promedios en la figura inferior. 
cell maxima was observed in the summer (January-March) mostly composed by Chrysophyceae particularly Dinobryon divergens. In biomass, diatoms were dominant particularly in the fall and spring sharing relevance with Xantophyceae (Fig. 4). Tribonema elongatum was the most relevant species within the latter group. Chrysophyceae mostly represented by Dinobryon were the main component in summer also followed by dinoflagellates in the fall (Fig. 4).
Temporal patterns of nutrients and phytoplankton in four lakes

Some limnological characteristics of sampled lakes are shown in Table 2. As in the Lake Llanquihue analysis, $\mathrm{NO}_{3}$ was the main nitrogen component of the DIN in the four lakes, while $\mathrm{PO}_{4}$ concentration was usually less than $50 \%$ of the total phosphorus content. Due to methodological problems, there were few measurements of or-

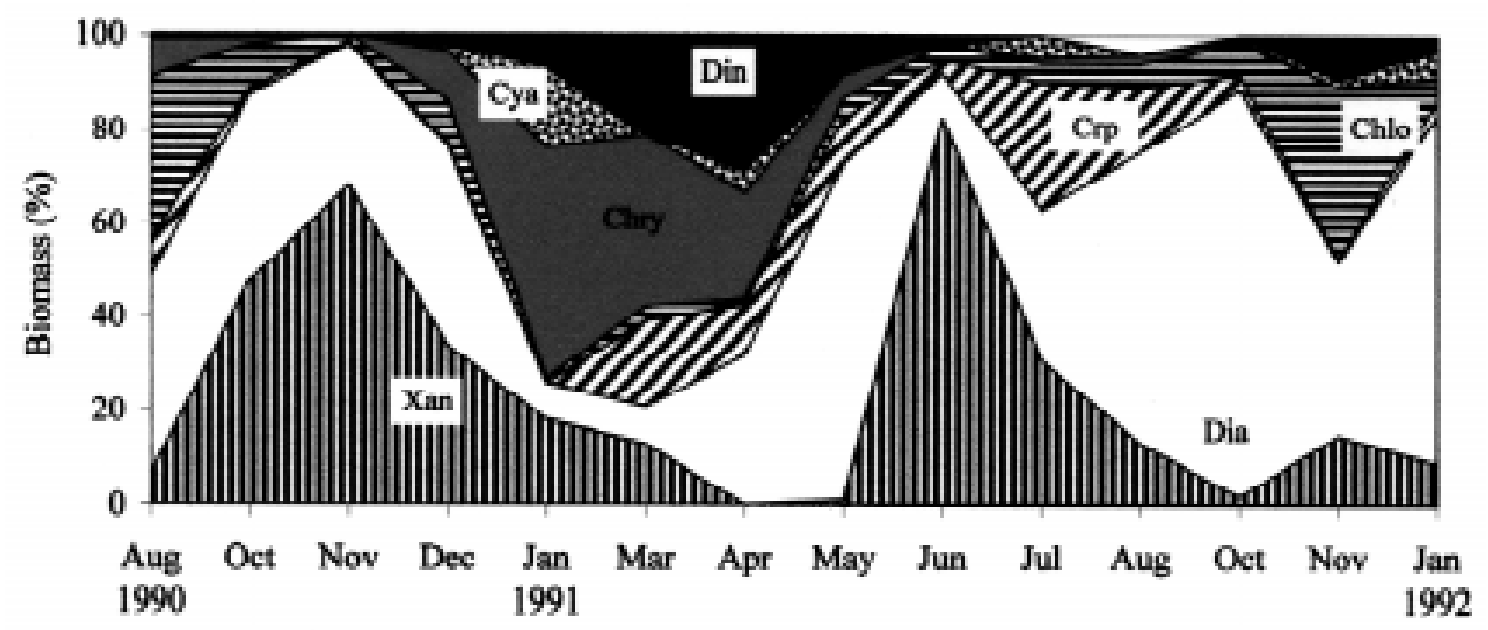

Fig. 4: Phytoplankton main groups and relative abundance in biomass, along the "in-lake" sampling period at lake Llanquihue. Chlorophyceae (Chlo), Xanthophyceae (Xan), Cyanophyceae (Cya), Chrysophyceae (Cry), Dinophyceae (Din), and Cryptophyceae (Crp).

Principales grupos fitoplanctónicos y su abundancia relativa en biomasa durante el período de muestreo "intra-lago" en el lago Llanquihue. Chlorophyceae (Chlo), Xanthophyceae (Xan), Cyanophyceae (Cya), Chrysophyceae (Cry), Dinophyceae (Din), Cryptophyceae (Crp) and Bacillariophyceae (Dia).

TABLE 2

Some morphological characteristics and average limnological variables $(n=14,1992-1999)$ of lakes, plus standard error (SE) shown below each average. Also, known mean values for previous periods are show above present study means

Algunas características morfológicas y variables limnológicas promedio ( $\mathrm{n}=14,1992-1999)$ de los lagos, el error estándar (EE) se muestra bajo cada promedio. También se indican valores promedio conocidos para períodos previos al presente estudio

\begin{tabular}{|c|c|c|c|c|c|c|c|c|}
\hline Lake & $\begin{array}{l}\text { Lake area } \\
\left(\mathrm{km}^{2}\right)\end{array}$ & $\begin{array}{l}\text { Mean depth } \\
(\mathrm{m})\end{array}$ & & $\begin{array}{c}\mathrm{TP} \\
\left(\mu \mathrm{g} \mathrm{L}^{-1}\right)\end{array}$ & $\begin{array}{c}\mathrm{PO} 4 \\
\left(\mu \mathrm{g} \mathrm{L}^{-1}\right)\end{array}$ & $\begin{array}{c}\mathrm{DIN} \\
\left(\mu \mathrm{g} \mathrm{L}^{-1}\right)\end{array}$ & $\begin{array}{c}\text { Chl-a } \\
\left(\mu \mathrm{g} \mathrm{L}^{-1}\right)\end{array}$ & $\begin{array}{l}\text { Secchi } \\
(\mathrm{m})\end{array}$ \\
\hline Llanquihue & 870 & 182 & $\begin{array}{c}\text { Mean 82-83a } \\
\text { Mean 92-99 } \\
\text { SE }\end{array}$ & $\begin{array}{l}3.2 \\
5.3 \\
(0.6)\end{array}$ & $\begin{array}{c}2.1 \\
(0.8)\end{array}$ & $\begin{array}{l}12.4 \\
(0.6)\end{array}$ & $\begin{array}{c}0.8 \\
1.0 \\
(0.1)\end{array}$ & $\begin{array}{l}15.5 \\
15.1 \\
(0.7)\end{array}$ \\
\hline Puyehue & 165 & 76 & $\begin{array}{c}\text { Mean } 86-87 b \\
\text { Mean } 92-99 \\
\text { SE }\end{array}$ & $\begin{array}{c}11.2 \\
8.1 \\
(0.9)\end{array}$ & $\begin{array}{c}3.6 \\
(0.9)\end{array}$ & $\begin{array}{l}31.2 \\
(2.2)\end{array}$ & $\begin{array}{l}2.1 \\
1.9 \\
(0.3)\end{array}$ & $\begin{array}{c}8.5 \\
8.3 \\
(0.4)\end{array}$ \\
\hline Rupanco & 236 & 162 & $\begin{array}{c}\text { Mean } 80-81^{c} \\
\text { Mean } 92-99 \\
\text { SE }\end{array}$ & $\begin{array}{c}3.6 \\
5.0 \\
(0.8)\end{array}$ & $\begin{array}{c}2.1 \\
(0.1)\end{array}$ & $\begin{array}{l}23.5 \\
(0.7)\end{array}$ & $\begin{array}{c}<1 \\
1.2 \\
(0.2)\end{array}$ & $\begin{array}{l}15.2 \\
14.4 \\
(0.3)\end{array}$ \\
\hline Yelcho & 120 & 135 & $\begin{array}{l}\text { Mean } \\
\text { SE }\end{array}$ & $\begin{array}{c}6.9 \\
(0.8)\end{array}$ & $\begin{array}{c}4.1 \\
(0.5)\end{array}$ & $\begin{array}{l}18.3 \\
(2.6)\end{array}$ & $\begin{array}{c}0.7 \\
(0.1)\end{array}$ & $\begin{array}{l}7.0 \\
(0.3)\end{array}$ \\
\hline
\end{tabular}

${ }^{a}$ Campos et al. (1988); ${ }^{b}$ Campos et al. (1989); ${ }^{\circ}$ Campos et al. (1992) 
ganic nitrogen and those concentrations were usually lower than $50 \mu \mathrm{g} \mathrm{L}^{-1}$. In general total nitrogen values rarely exceeded $100 \mu \mathrm{g} \mathrm{L}^{-1}$ while inorganic forms were usually about 30 to $40 \%$ of the total N. Total phosphorus concentrations were also low, averages ranging from 5 to $9 \mu \mathrm{g} \mathrm{L}^{-1}$. Concen- tration of Chl-a was very low on most sampling dates in all the lakes, the highest values were observed in Lake Puyehue and the lowest in Lake Yelcho (Table 2, Fig. 5). While average Secchi disk followed a reciprocal pattern as expected, highest values in Llanquihue and lowest in
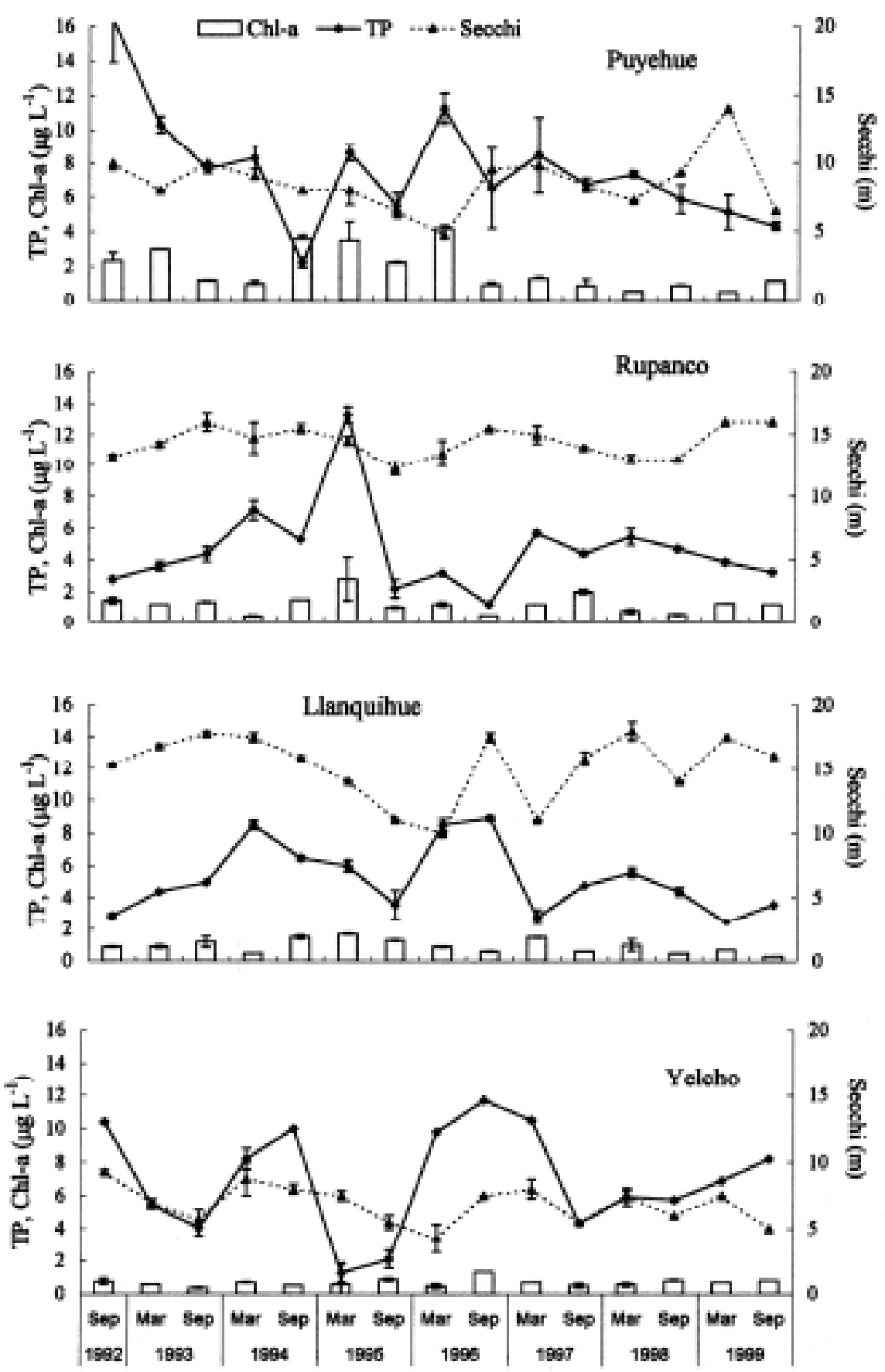

Fig. 5: Mean values $(\mathrm{n}=2)$ of chlorophyll a (Chl-a, bars), total phosphorus (TP, straight line) and Secchi disk (dashed line). Standard errors are indicated.

Valores promedio $(\mathrm{n}=2)$ de clorofila a $(\mathrm{Chl}-\mathrm{a}$, barras), fósforo total (TP, línea continua) y disco de Secchi (línea discontinua). Se muestran los errores estándar. 
Puyehue and Yelcho. The smallest Secchi values in lake Yelcho, which also has the lowest Chl-a, where mostly due to the influence of active glaciers in the area as there is a permanent flow of "glacier milk" in to the lake. The DIN values were also quite low, often less than $30 \mu \mathrm{g} \mathrm{L}^{-1}$, except during 1993 and particularly March 1994 in most places (Fig. 6) when an abrupt increase was observed. This increase was mostly due to higher nitrate concentrations. After that date there is a very low DIN period, which also produced low DIN/DIP ratios until the 1998-1999 period when there was a new increase in DIN concentrations particularly in lake Puyehue (Fig. 6). Despite these fluctuations there is no clear trend of increase or decrease in any of the lakes during the 8 years, except for the mentioned fluctuations during shorter periods. Similarly, the DIN/DIP molar ratio for the dissolved forms of both nutrients was often below 20 but without showing a clear temporal trend.
When all the point values relating Chl-a to TP or to DIN or DIN/DIP are combined in a multiple regression analysis there is no clear predictive pattern of Chl-a values from any of these variables or combinations of them. Such analyses were performed for each individual lake and for all of them combined. In all cases $\mathrm{R}^{2}$ values were lower than 0.3 and not statistically significant $(P$ $>0.1$ ). However, if we use averages for each lake, it is possible to see that the lake with greater TP and DIN content has the largest mean Chl-a (Table 2). The Chl-a, TP and DIN values measured during the 1992-99 period in lake Llanquihue were within the range of values measured in the in-lake comparison for the period 1990-1992 (Table 1 and 2).

Phytoplankton composition by major groups is shown in Fig. 7 where it can be seen that in lake Puyehue, dinoflagelates and green algae appear with greater frequency than in the other lakes where diatoms and Chrysophyceae are more com-
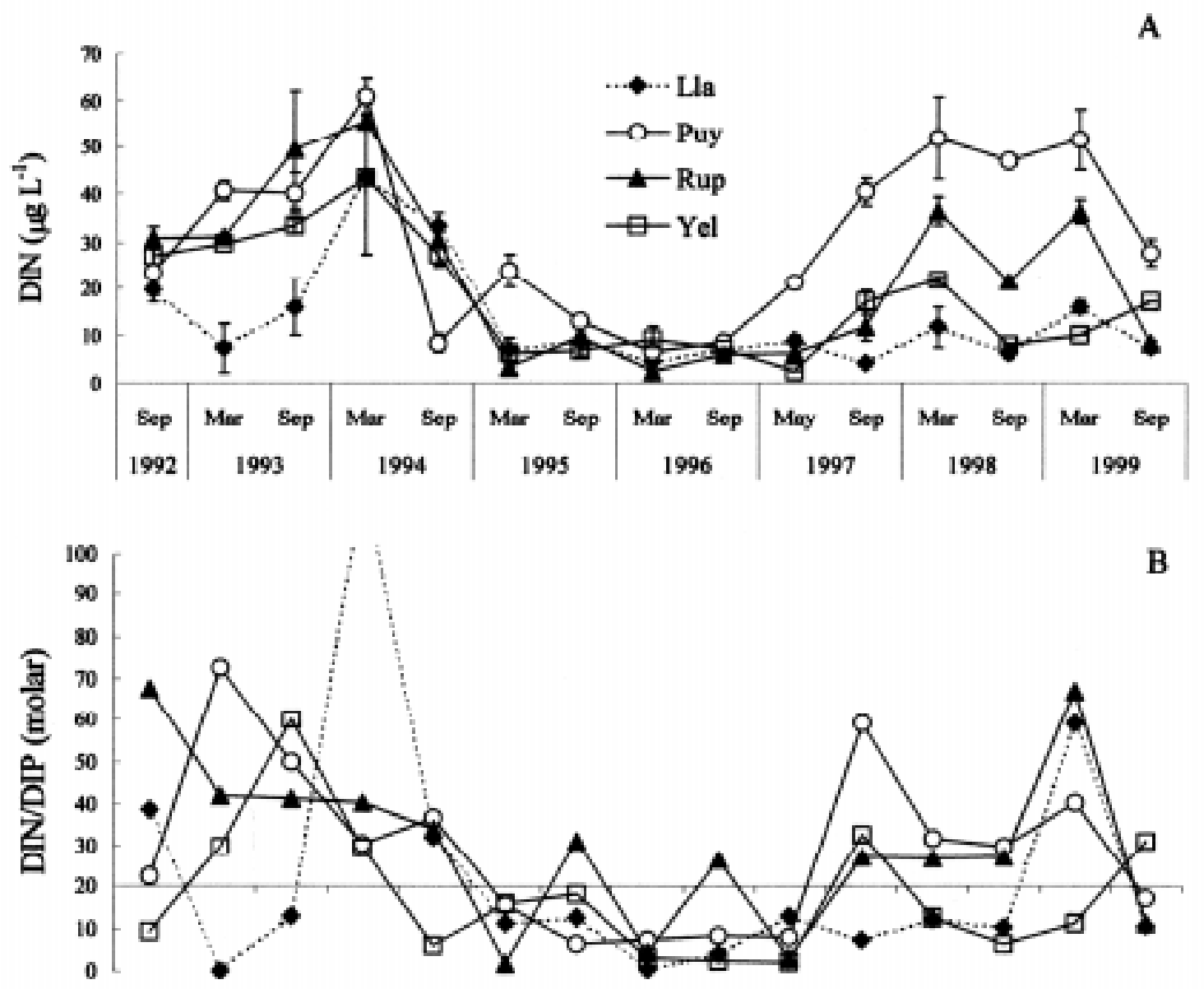

Fig. 6: Mean values for (A) dissolved inorganic nitrogen (DIN) and (B) ratio of DIN/ dissolved inorganic phosphorous (DIP).

Valores promedio para (A) nitrógeno inorgánico disuelto (DIN) y (B) la razón DIN/fósforo inorgánico disuelto (DIP). 
mon. The latter group is mostly absent from Puyehue, while the diversity of groups is greatest here. In a more extreme situation is lake Yelcho with the lowest diversity of groups and the more persistent diatom dominance.

\section{Experimental results}

In the limnocorral experiments performed in lake Llanquihue even though there was within treatment variation, nitrogen had the most significant effect on Chl-a concentration. The highest values were observed in the $\mathrm{N}$ treatment bags independently of the $\mathrm{P}$ additions or the light treatment
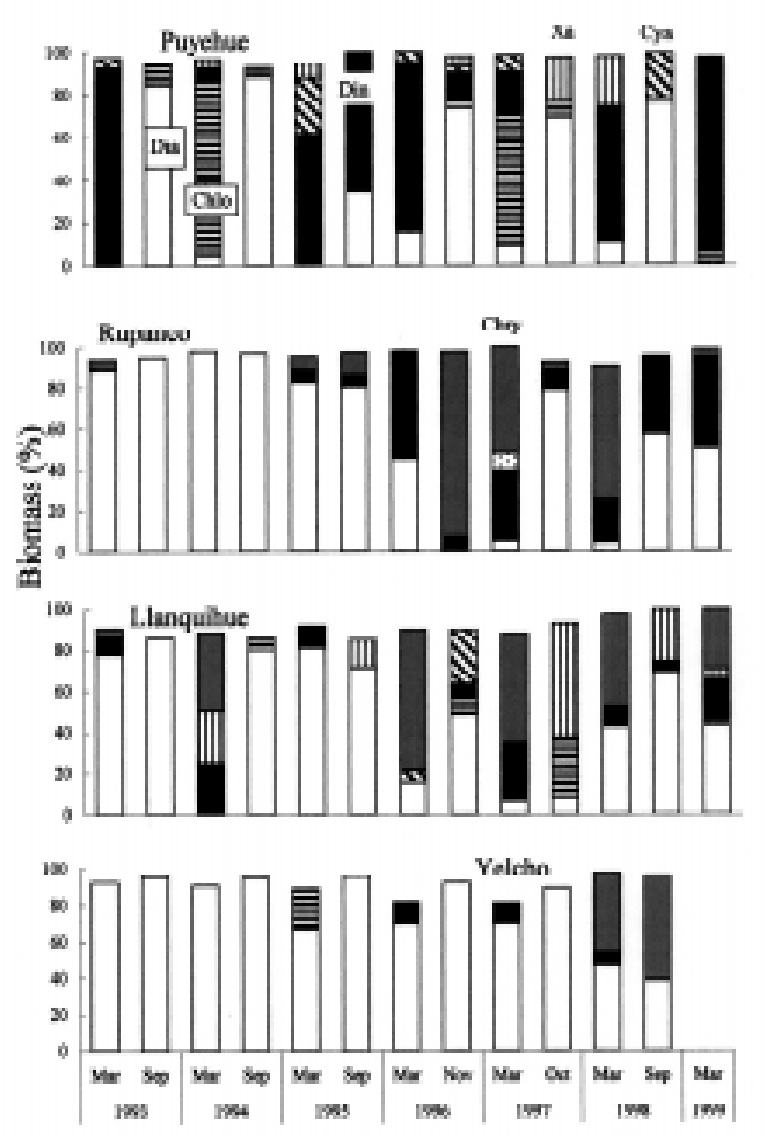

Fig. 7: Phytoplankton composition by major groups (\% biomass) for each of the four lakes during the study period. Bacillariophyceae (Dia), Chlorophyceae (Chlo), Dinophyceae (Din), Xanthophyceae (Xan), Cyanophyceae (Cya), and Chrysophyceae (Cry).

Composición del fitoplancton de acuerdo a los grupos principales (\% en biomasa) para cada uno de los cuatro lagos durante el período de estudio. Bacillariophyceae (Dia), Chlorophyceae (Chlo), Dinophyceae (Din), Xanthophyceae (Xan), Cyanophyceae (Cya), and Chrysophyceae (Cry).
(Table 3) as shown by the results of the block design factorial analysis (Table 4).

Another result was that Chl-a values in the control bags were significantly higher than values in the lake on each date except January 26 (Student t-test, $\mathrm{P}<0.05$ ). Initial values were 0.32 $\mu \mathrm{g} \mathrm{L}^{-1}$ while on January 22 the average value was two times that in the lake (Table 3).

\section{DISCUSSION}

Limnological condition of lakes: in-lake versus between-lake comparisons

Two situations are striking from the three-scale study; there is no clear effect of measured nutrients on Chl-a or phytoplankton both in the "inlake" and "between-lake" studies and there are no clear trends in the 8-year period. The four lakes seem to be still in an oligotrophic to mesotrophic state although one could argue that sampling twice a year may not be enough to include maximum Chl-a and phytoplankton blooms. Yet, sampling took place during the time period when algal increases are often seen and have been reported in independent lakes studies such as the Llanquihue case shown here. Indeed phytoplankton composition and temporal changes observed during this period (1990-1992), were very similar to those reported by Campos et al. (1988) for Llanquihue during the 1982-1983 period.

On the other hand, as expected, lake Puyehue with higher TP and DIN has more Chl-a (Table 2). One interesting temporal and "between-lake" pattern is that shown by major phytoplankton groups where the greater group diversity and frequency of dinoflagellates (Fig. 7) agrees with the higher TP content as is the case of Puyehue but also agrees with a lower mixing depth in this lake. Group diversity could perhaps be used as a good indicator of trophic state in these large lakes with deep mixing. Also nanoplankton species, such as the small Chrysochromulina spp. and Cyclotella spp. which are functionally relevant in small Andean lakes (Balseiro et al. 1997), could also play important roles here and they should be explored.

Yet, an 8-year period may not be enough in this type of lake, to detect important changes, and as seen in Puyehue the mean value for the 8 years is smaller than the annual mean of 1982-1983 although the two means are not significatively different $(P>0.1)$. More intriguing is the fact that in Lake Llanquihue there were no site effects on Chl-a (Fig. 3), while DIN and TP concentrations were higher in salmon farm bays and yet in this 
case in particular TP is not a good predictor of Chl-a.

This lake supports more than 2,500 tons of salmon smolt production every year which, through the feeding process, could supply around 32 tons of $\mathrm{P}$ and 120 tons of $\mathrm{N}$ annually. However among site differences do not seem to be large enough to produce differences in Chl-a content or, Chl-a and phytoplankton are responding to other more important stressors such as, turbulence and mixing. It seems that these lakes have less Chl-a than expected given the $\mathrm{N}$ and $\mathrm{P}$ concentrations and despite of the nutrient inputs from salmon farming.

Two issues are clear, first of all, both $\mathrm{P}$ and $\mathrm{N}$ values are quite low, particularly the latter, com- pared with values measured in aquatic systems in the world as shown by Guildford \& Hecky (2000). When average molar data of 13 Araucanian and North Patagonian lakes are pooled together, TN values do not exceed $20 \mu \mathrm{mol} \mathrm{L^{-1 }}$ and TP do not exceed $0.8 \mu \mathrm{mol} \mathrm{L}^{-1}$ (Fig. 8). Variation measures were not included in the graphs since mean values for the four lakes studied here are for 8-year data while in all the other cases values are mean values for independent annual studies. However in most cases standard errors would not be greater than the symbol size for the mean value in the graphs. Values for TP, and especially for TN and Chl-a shown here, are more similar to those found in very oligotrophic lakes such as Lake Malawi in Africa (Guildford \& Hecky 2000).

TABLE 3

Source of variation, $\mathrm{F}$ and $P$ values for a three way ANOVA on Chl-a concentrations on each sampling date

Fuente de variación, valores de F y P para el ANDEVA de las concentraciones de Chl-a en cada fecha. Ausencia de significancia estadística se indica como "NS", en tanto los efectos significativos se indican como: $\mathrm{P}<0,05$ (*); P < $0,01(* *) ; \mathrm{P}<0,001(* * *)$

\begin{tabular}{|c|c|c|c|c|c|c|c|}
\hline Source & $\begin{array}{l}\text { Degrees } \\
\text { of freedom }\end{array}$ & $\begin{array}{r}\text { F-value } \\
\mathrm{Ja}\end{array}$ & $\begin{array}{l}P \text {-value } \\
\text { y } 22\end{array}$ & $\begin{array}{r}\text { F-value } \\
\text { Janu }\end{array}$ & $\begin{array}{l}P \text {-value } \\
26\end{array}$ & $\begin{array}{r}\text { F-value } \\
\text { Janu }\end{array}$ & $\begin{array}{l}P \text {-value } \\
\text { y } 30\end{array}$ \\
\hline Light & 1 & 0.000 & NS & 3.362 & NS & 0.219 & NS \\
\hline Phosphorus & 1 & 0.185 & NS & 0.262 & NS & 1.065 & NS \\
\hline Nitrogen & 1 & 25.311 & $* * *$ & 13.728 & $* *$ & 37.185 & $* * *$ \\
\hline Interactions & & & & & & & \\
\hline Light $\times$ P & 1 & 1.320 & NS & 6.288 & $*$ & 0.283 & NS \\
\hline Light $x \mathrm{~N}$ & 1 & 0.779 & NS & 1.718 & NS & 0.043 & NS \\
\hline $\mathrm{P} \times \mathrm{N}$ & 1 & 0.269 & NS & 0.895 & NS & 1.689 & NS \\
\hline Light $\times P \times N$ & 1 & 1.265 & NS & 7.325 & $*$ & 0.012 & NS \\
\hline Error & 16 & & & & & & \\
\hline
\end{tabular}

TABLE 4

Mean chlorophyll a values \pm 1 SE for each treatment and for the lake, before experimental manipulation (January 18) and on three sampling dates after the experiment started

Valores promedio de Chl-a \pm 1 EE para cada tratamiento y para el lago, antes de la manipulación experimental (enero 18) y en las tres fechas posteriores al comienzo del experimento

\begin{tabular}{|c|c|c|c|c|c|}
\hline Date & Control & $\mathrm{N}$ & $\mathrm{P}$ & NP & Lake \\
\hline $\begin{array}{l}\text { 18-January } \\
\text { 22-January }\end{array}$ & $0.37 \pm 0.3 *$ & & & & $\begin{array}{l}0.32 \pm 0.8 \\
0.63 \pm 0.12\end{array}$ \\
\hline $50 \%$ light & $1.44 \pm 0.48$ & $4.73 \pm 0.19$ & $1.39 \pm 0.8$ & $7.2 \pm 1.7$ & \\
\hline $100 \%$ light & $2.1 \pm 0.3$ & $5.8 \pm 1.7$ & $2 \pm 0.2$ & $4.8 \pm 1.6$ & \\
\hline $\begin{array}{l}\text { 26-January } \\
50 \% \text { light } \\
100 \% \text { light }\end{array}$ & $\begin{array}{r}0.60 \pm 0.1 \\
0.5 \pm 0.2\end{array}$ & $\begin{array}{l}1.3 \pm 0.15 \\
1.7 \pm 0.5\end{array}$ & $\begin{array}{l}0.7 \pm 0.1 \\
0.6 \pm 0.1\end{array}$ & $\begin{array}{r}2 \pm 0.6 \\
0.4 \pm 0.2\end{array}$ & $0.57 \pm 0.1$ \\
\hline $\begin{array}{l}\text { 30-January } \\
50 \% \text { light } \\
100 \% \text { light }\end{array}$ & $\begin{array}{l}1.2 \pm 0.03 \\
1.2 \pm 0.1\end{array}$ & $\begin{array}{l}2.6 \pm 0.2 \\
2.7 \pm 0.8\end{array}$ & $\begin{array}{l}0.9 \pm 0.2 \\
1.3 \pm 0.2\end{array}$ & $\begin{array}{l}3.4 \pm 0.6 \\
3.6 \pm 1.4\end{array}$ & $0.46 \pm 0.2$ \\
\hline
\end{tabular}

\footnotetext{
*Chlorophyll values were measured in three bags at random before adding nutrients
} 


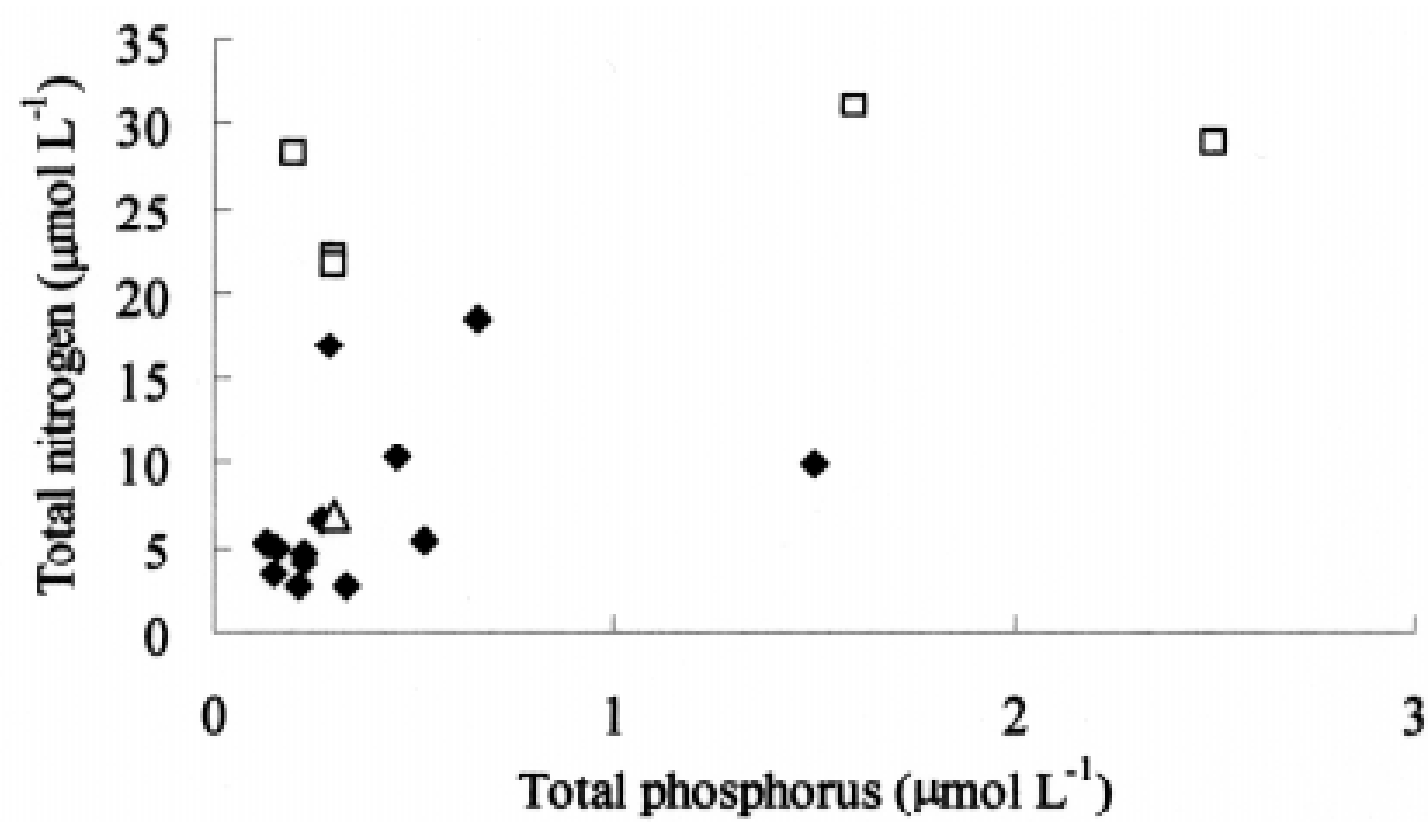

Fig. 8: Values of TN and TP in temperate lakes based on Guilford \& Hecky (2000), squares represent averages for European and North American lakes and lake Victoria in Africa. Open triangle represents lake Malawi in Africa. Filled symbols are averages for southern Chilean lakes.

Valores de TN y TP en lagos templados de acuerdo a la información presentada por Guilford \& Hecky (2000), los cuadrados representan promedios para lagos europeos, norteamericanos y el lago Victoria en África. El triángulo abierto representa el Lago Mallawi en África. Los rombos negros representan promedios para lagos del sur de Chile.

The second significant issue is that N/P ratios are low enough to suspect some $\mathrm{N}$ limitation (Fig. 6 and 9). This suggestion is also supported by the limnocorral results in Lake Llanquihue (Table 3 and 4). Conversely Steinhart et al. (1999) in almost simultaneous and similar limnocorral experiments, in lake Chaiquenes $\left(41^{\circ} 35^{\prime} \mathrm{S}\right)$ found more evidence for P limitation. Yet, Steinhart (1996, unpublished results) performed further studies including physiological assays for nutrient limitation as suggested by Hecky et al. (1993), and found some evidence for $\mathrm{N}$ limitation in at least the Araucanian lakes area.

Nitrogen limitation is quite possible in these Southern Hemisphere lakes (Soto et al. 1994) and creates one of the largest differences between the Southern and Northern Hemisphere. A large proportion of the $\mathrm{N}$ content in terrestrial ecosystems and water bodies in the Northern Hemisphere is due to industrial contamination of precipitation (Vitousek et al.1997). While in the Southern Hemisphere due to the much lower and recent industrial development, anthropogenic nitrogen inputs in precipitation are very low particularly inorganic nitrogen as shown in southern Chile (Hedin et al. 1995, Galloway et al. 1996). Indeed lakes in southern South America are very low in nitrogen and it could be suggested that lakes in the North- ern Hemisphere were like this before industrial revolution so $\mathrm{P}$ limitation develops as $\mathrm{N}$ becomes more freely available. This is also an additional explanation to the $\mathrm{N}$ limitation in tropical aquatic ecosystems, which is so often related to land-use changes (Downing et al. 1999). Perhaps an interesting comparison is that offered by lake Tahoe in northern California, a deep oligotrophic lake quite comparable to lake Llanquihue, which has been slowly changing from being $\mathrm{N}$ limited to $\mathrm{P}$ limited, probably due to atmospheric deposition (Goldman et al. 1993).

However nutrient limitation does not seem to be the only explanation for the low Chl-a values, an alternative explanation relates to the much deeper epilimnion in these Chilean lakes which may enhance light related stress and/or greater UVB effects.

Limnocorral experiments versus lake monitoring: nutrients versus disturbance

Although both descriptive and experimental approaches described here could support the effects of some nutrient limitation, more meaningful comparisons could be precluded because of obvious differences in temporal and spatial scales. In- 


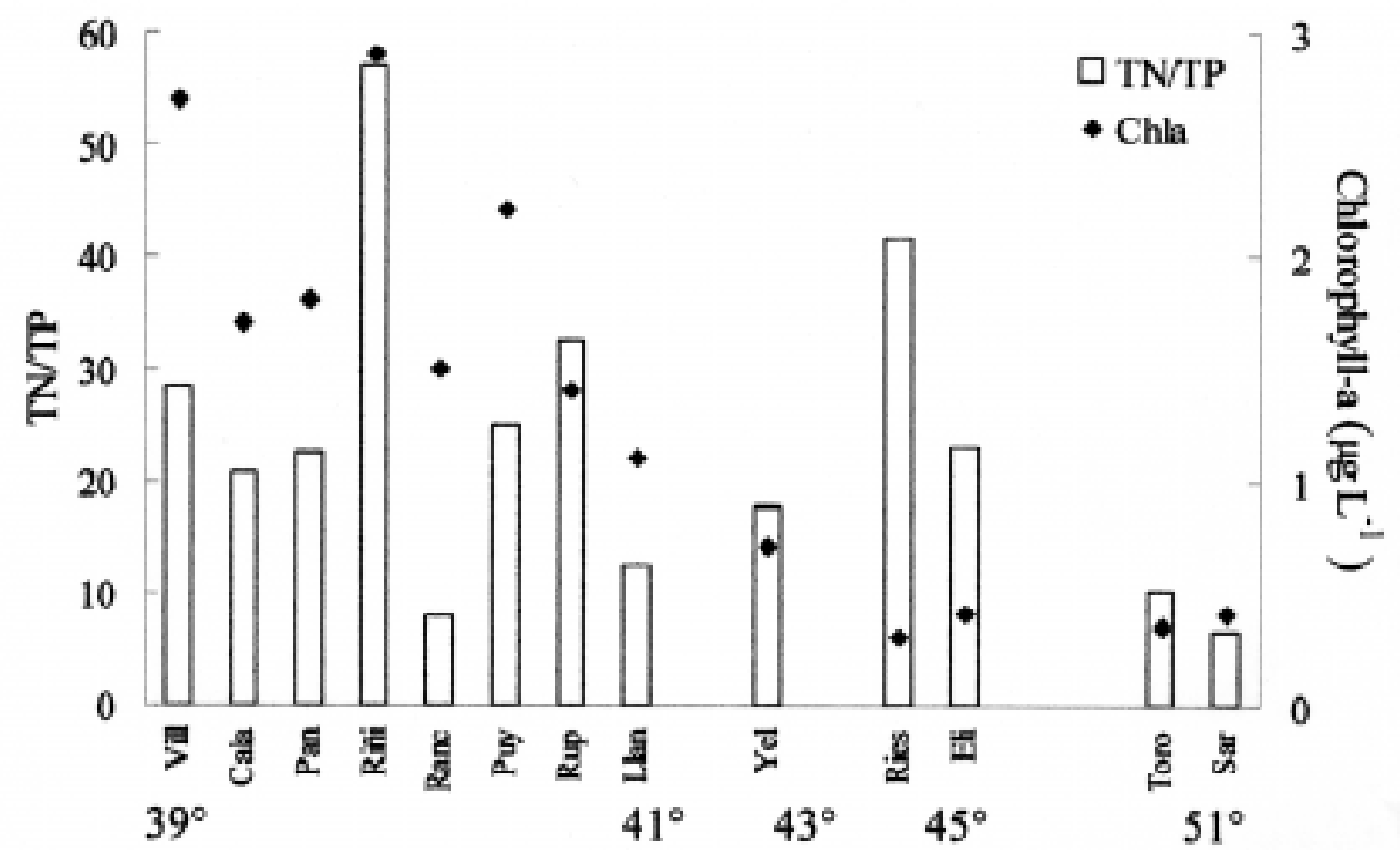

Fig. 9: Average molar TN/TP ratio and Chl-a for lakes in southern Chile along a latitudinal gradient. Razón TN/TP molar promedio y Chl-a para lagos del sur de Chile a lo largo de un gradiente latitudinal.

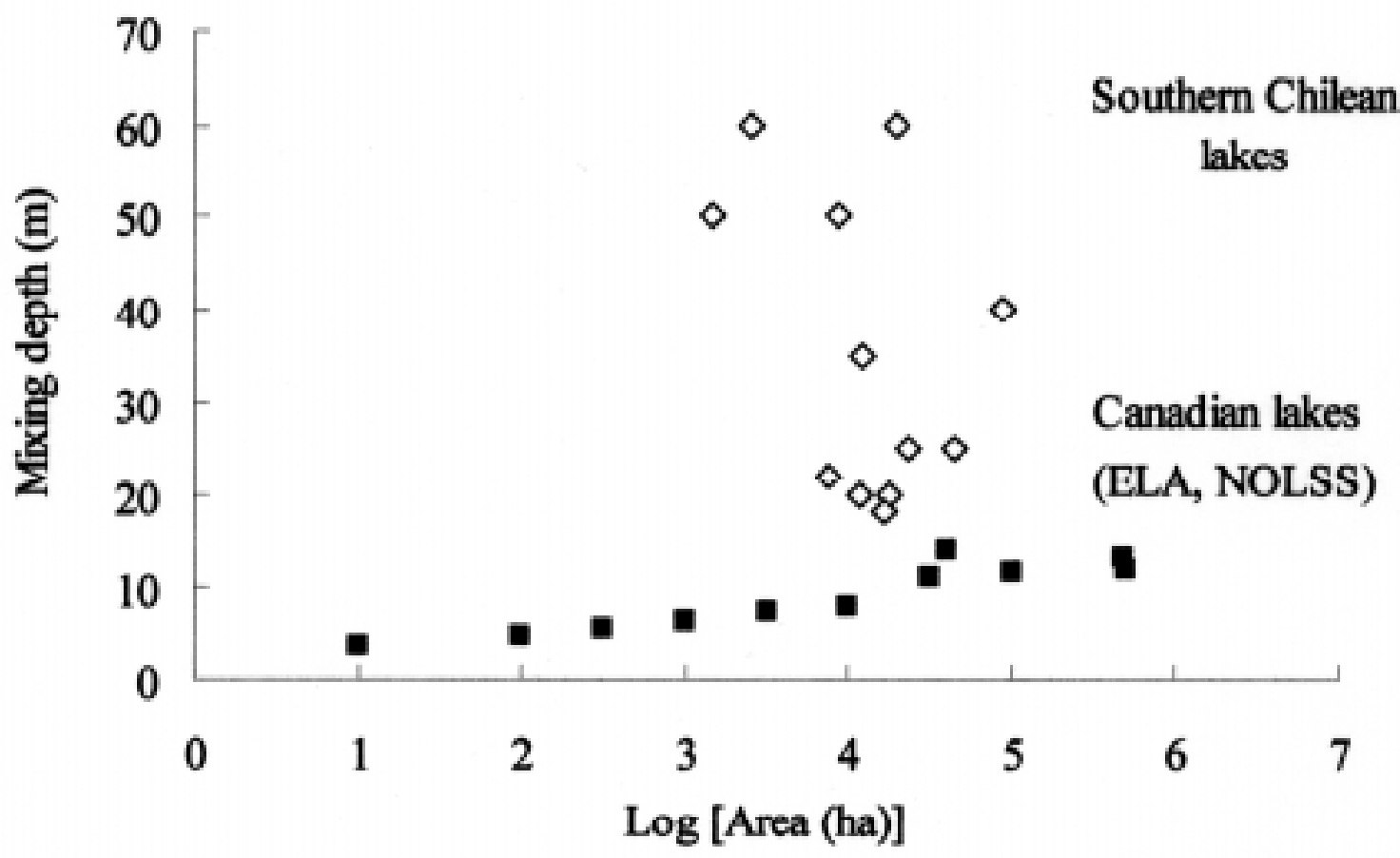

Fig. 10: Mixing depth-area relationship for southern Chilean lakes. Each lake is represented by one open figure. Comparable Canadian lakes (ELA, NOLSS, Fee \& Hecky 1992, Fee et al. 1992, 1994, 1996), each lake is represented by one filled square.

Relación profundidad de mezcla-área para lagos del sur de Chile. Cada lago es representado por un rombo abierto. Lagos Canadienses comparables (ELA, NOLSS, Fee \& Hecky 1992, Fee et al. 1992, 1994, 1996), cada lago representado por un cuadrado relleno. 
deed, bags constrain the mixing impacts on phytoplankton, whereas this occurs in the natural environment. This would explain the increase in $\mathrm{Chl}-\mathrm{a}$ in the control bags with respect to the lake Chl-a (Table 3), while there was no evidence of total radiation (including UV) negatively affecting Chl-a (Table 3 and 4). A similar Chl-a increase was observed in control bags in the experiments performed by Steinhart et al. (1999) and thus two potential "bag-effects" can be provided as explanations; (a) nutrients, even at very low concentrations, are retained longer in the short water column, (b) algae experience a more even and less variable light regime than they would if they were in 30- to $40-\mathrm{m}$ mixing water column. The latter is the more reasonable explanation given the following arguments.

Indeed, the key regulating factor could relate to the deep mixing even in summer, which is a particular characteristic of Southern Hemisphere lakes. Figure 10 shows a comparative view of North American temperate lakes (data from Fee \& Hecky 1992 and Fee et al. 1992, 1994, 1996), and Chilean lakes. Here, the different mixing patterns are evident since for similar lake area, Chilean lakes have much deeper epilimnion. Baigun \& Marinone (1995) have already noticed such deep mixing, however they did not offer a clear connection to explain the slower response of Chl-a to nutrient inputs and the general low
Chl-a values in Argentinean lakes. The reason for such deeper mixing relates to the much smaller land mass of the southern portion of South America (but also true for New Zealand) compared to that of North America, Europe and Asia. Water bodies located in such smaller land-masses are more exposed to winds and local climate is buffered by the oceans, thus most temperate lakes in the Southern Hemisphere are monomictic and do not freeze in winter.

Thus lake Puyehue can probably support more dinoflagellates in late summer (Fig. 7) not necessarily because it has more nutrients but because it develops a comparatively shallower epilimnion than do lakes Rupanco or Llanquihue (Table 2). The relevance of mixing and disturbance for biological production has been deeply reviewed by Reynolds (1998) among others.

Yet the relevance of the deep epilimnion is not clear and deserves further research since light availability and quality could play opposite roles controlling phytoplankton growth. On the one hand phytoplankton could be exposed to UV, especially suffering sudden UV exposure when the algal cell is moving vertically along with the water within short periods of time. Deep mixing could in fact not allow for photoadaptation (Cullen \& Lewis 1988, Montecino et al. 1997).

Conversely, at times, it is also possible that phytoplankton in a deep epilimnion are receiving

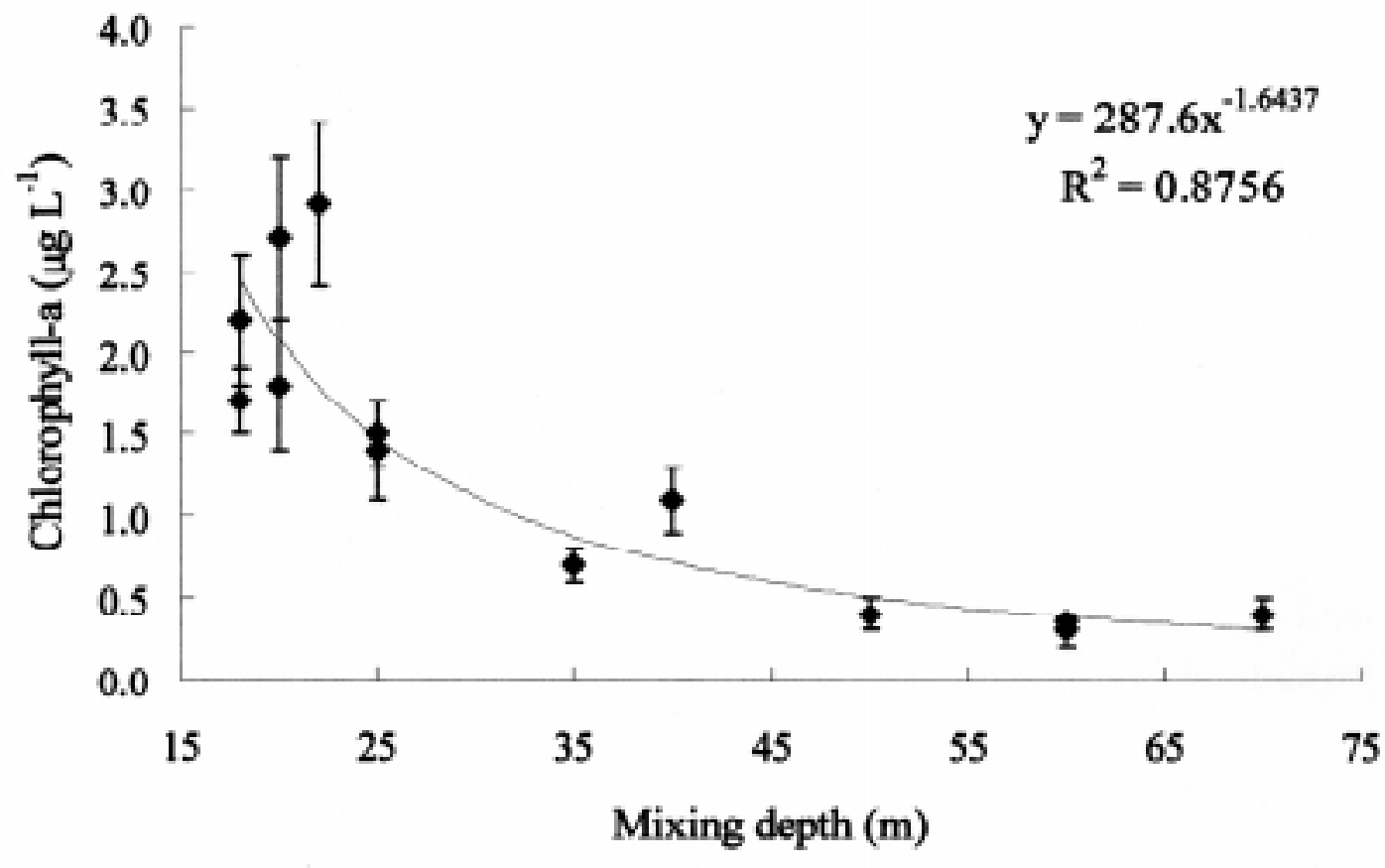

Fig. 11: Average summer Chl-a vs mixing depth for southern Chilean lakes. Bars represent standard error for monthly measurements (November through March).

Promedio de Chl-a en el verano vs profundidad de mezcla en lagos del sur de Chile. Las barras representan error estándar para muestreos mensuales (noviembre a marzo). 
on average less PAR irradiance than phytoplankton on a shallower epilimnion even with similar euphotic zones. This "light related stress or limitation" could also explain the increase in the Chla values in the control bags in the experiment shown here but also in that performed by Steinhart et al. (1999). Indeed, mixing depth is the best predictor of Chl-a in these lakes (Fig. 11). Given such a relationship, a threshold for the relevance of mixing depth on lake productivity can be proposed at about $25 \mathrm{~m}$. Thus, some lakes such as Villarrica, Calafquén, Riñihue, with mixing depths lower than $25 \mathrm{~m}$ should be more sensitive to nutrient additions particularly $\mathrm{N}$.

Mixing depth also increases from north to south in Chile and Argentina (Geller et al. 1992, 1997), and lakes in southern most part of South America have even greater mixing depths than those of the Araucanian region. The lake Llanquihue $\left(41^{\circ} \mathrm{S}\right)$ epilimnion at the end of summer reaches to $40 \mathrm{~m}$, while lake Toro in Torres del Paine $\left(51^{\circ} \mathrm{S}\right)$ shows a very unstable stratification below $70 \mathrm{~m}$ (Campos et al. 1994a, 1994b). When the mean Chl-a values are plotted together with the TN/TP ratio in a latitudinal gradient for all the studied Chilean Andean lakes, a decrease in Chl-a is observed with increasing latitude (Fig. 9), which could relate to mixing depth, temperature and light gradients. Similar results were observed by Montecino (1991) with integrated Chl-a values in some of the same lakes.

This paper cannot presume of identifying all the relevant limnological mechanisms and allimportant components of the ecosystem. However the typical limnological variables, which are measured for environmental monitoring and environmental evaluation of lakes were considered. The challenges now are to decipher the true mechanisms and consequences of the deep mixing and the interplay with nutrient availability for planktonic production.

The light:nutrient ratio as proposed by Sterner et al. (1997) could be low in these lakes, and less carbon could be expected given nutrient inputs as compared with most Northern Hemisphere lakes, and thus total production of the pelagic zone should be low.

As a consequence of this, food webs should be linked rather to the benthos than to the pelagic zone particularly in the deepest mixing lakes, which has been already pointed out by Soto \& Campos (1995). If nutrients increase, particularly $\mathrm{N}$, a faster response in lakes with shallower epilimnia should be expected. Such response could imply increasing piscivory when biomass is available in the water column to sustain more prey fish. Finally, it is important to mention that in- creasing nutrient inputs from activities such as salmon farming and agriculture could have important effects, particularly in shallow bays, where eutrophication signs could show up early. Thus, the mixing effect could contribute to intra-lake variability when extensive shallow bays are present within large lakes.

\section{ACKNOWLEDGEMENTS}

I thank Vivian Montecino and Steffan Woelfl for providing enriching discussions on this subject. I also thank Colin Reynolds, and Gene Likens for constructive criticisms to this manuscript, remaining mistakes are my own. I am particularly grateful to Everett Fee who pointed out to me the relevance of light in the water column in a mixing environment. I am very grateful to Gail Steinhart for field and equipment assistance and for enlightening discussions. I am also grateful to all the students and technicians of the "Laboratorio de Ecología Acuática" for their invaluable field assistance through these years. Partial funding for this research was provided by Dirección de Investigación, Universidad Austral de Chile, DID 92-22. Marine Harvest Chile provided funds and the opportunity to collect long term data in some of the oligotrophic lakes. This is also a contribution to the Program of the Institute of Ecosystem Studies, Millbrook, New York. I dedicate this paper to the memory of Dr. Hugo Campos C. whose pioneer research and contribution to Chilean limnology made this work possible.

\section{LITERATURE CITED}

BAIGUN C \& MC MARINONE (1995) Cold-temperate lakes of South America: do they fit Northern Hemisphere models? Archivs für Hydrobiologie 135: 2351.

BALSEIRO EG, BE MODENUTTI \& CP QUEIMALIÑOS (1997) Nutrient recycling and shifts in N:P ratio by different zooplankton structures in a south Andes lake. Journal of Plankton Research 19: 805-817.

CAMPOS H (1984) Limnological studies of Araucanian lakes. Internationale Vereinigung für Theoretische und Angewandte Limnologie, Verhandlungen 22: 1319-1327.

CAMPOS H (1996) Estudios limnológicos de los lagos Elizalde y Riesco. Informe final, Dirección General de Aguas (DGA), Ministerio de Obras Públicas, Santiago, Chile. 176 pp.

CAMPOS H, W STEFFEN, C ROMÁN, LR ZÚÑIGA \& G AGÜERO (1983) Limnological studies in Lake Villarrica: morphometric, physical, chemical, planktonical factors and primary productivity. Archiv für Hydrobiologie (Supplement) 4: 371-406. 
CAMPOS H, W STEFFEN, G AGÜERO, O PARRA \& LR ZÚÑIGA (1987) Limnology of Lake Riñihue. Limnologica (Berlin) 18: 339-357.

CAMPOS H, W STEFFEN, G AGÜERO, O PARRA \& LR ZÚÑIGA (1988) Limnological studies of Lake Llanquihue (Chile), morphometry, physics, chemistry, plankton and primary productivity. Archivs für Hydrobiologie (Supplement) 81: 37-67.

CAMPOS H, W STEFFEN, G AGÜERO, O PARRA \& LR ZÚÑIGA (1989) Estudios limnológicos en el lago Puyehue (Chile): morfometria, factores físicos y químicos, plancton y productividad primaria. Medio Ambiente (Chile) 10: 36-53.

CAMPOS H, W STEFFEN, G AGÜERO, O PARRA \& LR ZÚÑIGA (1992) Limnological studies of Lake Rupanco (Chile), morphometry, physics, chemistry, plankton and primary productivity. Archivs für Hydrobiologie (Supplement) 90: 85-113.

CAMPOS H, D SOTO, W STEFFEN, G AGÜERO, O PARRA \& LR ZÚÑIGA (1994a) Limnological studies of Lake del Toro, Chilean Patagonia. Archivs für Hidrobiologie 99: 199-215.

CAMPOS H, D SOTO, W STEFFEN, G AGÜERO, O PARRA \& LR ZÚÑIGA (1994b) Limnological studies of Lake Sarmiento, a subsaline lake from Chilean Patagonia. Archivs für Hidrobiologie 99: 217-234.

CULLEN J \& W LEWIS (1988) The kinetics of photoadaptation in the context of vertical mixing. Journal of Plankton Research 10: 1039-1063.

DOWNING J, M MACCLAIN, R TWILLEY, J MELACK, J ELSER, N RABALAIS, W LEWIS, R TURNER, J CORREDOR, D SOTO, A YÁÑEZ-ARANCIBIA, A KOPASKA \& RH HOWARTH (1999) The impact of accelerating land-use change on the $\mathrm{N}$-cycle of tropical aquatic ecosystems- current conditions and projected changes (review). Biogeochemistry 46: 109148.

FEE EJ \& RE HECKY (1992) Introduction to the Northwest Ontario Lake Size Series (NOLSS). Canadian Journal of Fisheries and Aquatic Sciences 49: 24342444.

FEE EJ, JA SHEARER, ER DEBRUYN \& EU SCHINDLER (1992) Effects of lake size on phytoplankton photosynthesis. Canadian Journal of Fisheries and Aquatic Sciences 49: 2445-2459.

FEE EJ, RE HECKY, GW REGEHR, LL HENDZEL \& P WILKINSON (1994) Effects of lake-size on nutrient availability in the mixed-layer during summer stratification. Canadian Journal of Fisheries and Aquatic Sciences 51: 2756-2768.

FEE EJ, RE HECKY, M KASIAN \& DR CRUIKSHANK (1996) Effects of lake size, water clarity, and climatic variability on mixing depths in Canadian shield lakes. Limnology \& Oceanography 41: 912-920.

GALLOWAY JN, WE KEENE \& GE LIKENS (1996) Processes controlling the composition of precipitation at a remote southern hemispheric location: Torres del Paine National Park, Chile. Journal of Geophysical Research 101: 6883-6897.

GELLER W (1992) The temperature stratification and related characteristics of Chilean lakes in mid-summer. Aquatic Sciences 54: 37-57.
GELLER W, S HANNAPPEL \& H CAMPOS (1997) Temperature and stratification of southern temperate lakes in Patagonia (Chile, Argentina). Internationale Verein für Theoretische und Angewandte Limnologie, Verhandlungen 26: 243-247.

GOLDMAN CR, AD JASSBY \& SH HACKLEY (1993) Canadian Journal of Fisheries and Aquatic Sciences 50: 1489-1496.

GUILDFORD SJ \& RE HECKY (2000) Total nitrogen, total phosphorous, and nutrient limitation in lakes and oceans: is there a common relationship? Limnology \& Oceanography 45: 1213-1223.

HECKY RE, P CAMPBELL \& LL HENDZEL (1993) The stoichiometry of carbon, nitrogen, and phosphorus in particulate matter of lakes and oceans. Limnology \& Oceanography 38: 709-724.

HEDIN LO, J ARMESTO \& AH JOHNSON (1995) Patterns of nutrient loss from unpolluted, old growth temperate forests: evaluation of biogeochemical theory. Ecology 76: 493-509.

MONTECINO V (1991) Primary productivity in South American temperate lakes and reservoirs. Revista Chilena de Historia Natural 64: 555-567.

MONTECINO V, G PIZARRO \& G MARTÍNEZ (1997) Optical climate (PAR and UV) and phytoplankton dynamics in a high mountain Andean lake (Laguna Negra, Chile). Internationale Verein für Theoretische und Angewandte Limnologie, Verhandlungen 26: 441445.

MORRIS DP, H ZAGARESE, C WILLIAMSON, E BALSEIRO, B HARGREAVES, B MODENUTTI, R MOELLER \& C QUEIMALIÑOS (1995) The attenuation of solar UV radiation in lakes and the role of dissolved organic carbon. Limnology \& Oceanography 40: 1381-1391.

NEALE PJ (1987) Algal photoinhibition and photosynthesis in the aquatic environment. In: Kyle W, D Osmond \& CB Arntze (eds) Photoinhibition: 33-36. Elsevier, Amsterdam, The Netherlands.

NEALE PJ, JF TALLING, S HEANEY, C REYNOLDS \& WG LUND (1991) Long time series from the English Lake District: irradiance-dependent phytoplankton dynamics during the spring maximum. Limnology \& Oceanography 36: 751-760.

REYNOLDS CS (1998) What factors influence the species composition of phytoplankton in lakes of different trophic status? Hydrobiologia 369: 11-26.

SCHINDLER DW (1997) Widespread effects of climatic warming on freshwater ecosystems in North America. Hydrological Processes 11: 1043-1067.

SOTO D, H CAMPOS, O PARRA, L ZÚÑIGA \& W STEFFEN (1994) The Torres del Paine Lake district (Chilean Patagonia): a case of pristine N-limited lakes and ponds. Archivs für Hidrobiologie 99: 181-197.

SOTO D \& H CAMPOS (1995) Los lagos oligotroficos asociados al bosque templado húmedo del sur de Chile. In: Armesto J, M Khalin \& C Villagrán (eds) Ecología de los bosques templados de Chile: 134148. Editorial Universitaria, Santiago, Chile. 
SOTO D \& J STOCKNER (1996) Oligotrophic lakes in southern Chile and in British Columbia: basis for their resilience to present and future disturbances. In: Lawford R, P Alaback \& E Fuentes (eds) High latitude rain forest of the west coast of the Americas: climate, hydrology, ecology and conservation: 266280. Springer-Verlag, New York, New York. 116 pp.

SOTO D \& G MENA (1999) Filter feeding by the freshwater mussel Diplodon chilensis as a biocontrol of salmon farming eutrophication. Aquaculture 171: 65-81.

STEINHART G (1996) Nutrient limitation of primary production and nutrient deficiency in phytoplankton in southern Chilean lakes. Master of Science Thesis, Cornell University, Ithaca, New York. 123 pp.

STEINHART G, G LIKENS \& D SOTO (1999) Nutrient limitation in Lago Chaiquenes (Parque Nacional Alerce Andino, Chile): evidence from nutrient enrichment experiments and physiological assays. Revista Chilena de Historia Natural 72: 559-568.

STERNER R, J ELSER, E FEE, S GUILFORD \& $T$ CHRZANOWSKI (1997) The light:nutrient ratio in lakes; the balance of energy and materials affects ecosystem structure and process. American Naturalist 150: 663-684.

Associate Editor: V. Montecino

Received January 15, 2001; accepted January 2, 2002
VILLAFAÑE VE, M ANDRADE, V LAIRANA, F ZARATTI \& EW HELBLING (1999) Inhibition of phytoplankton photosynthesis by solar ultraviolet radiation: studies in lake Titicaca, Bolivia. Freshwater Biology 42: 215-224.

VINCENT WF, PJ NEALE \& PJ RICHERSON (1984) Photoinhibition: algal responses to bright light during dial stratification and mixing in a tropical alpine lake. Journal of Phycology 20: 201-211.

VITOUSEK PM, JD ABER, RW HOWARTH, GE LIKENS, PA MATSON, DW SCHINDLER, WH SCHLESINGER \& DG TILMAN (1997) Human alteration of the global nitrogen cycle: sources and consequences. Ecological Applications 7: 737-750.

WETZEL RG \& GE LIKENS (2000) Limnological analyses. Third edition. Springer-Verlag, New York, New York. 429 pp. 